Article

\title{
Performance Evaluation of Flat Plate and Vacuum Tube Solar Collectors by Applying a $\mathrm{MWCNT} / \mathrm{Fe}_{3} \mathrm{O}_{4}$ Binary Nanofluid
}

\author{
Minjung Lee ${ }^{1}$, Yunchan Shin ${ }^{1}$ and Honghyun Cho ${ }^{2, *}$ \\ 1 Department of Mechanical Engineering, Graduate School of Chosun University, 303 Pilmun-daero, Dong-gu, \\ Gwangju 501-759, Korea; nov0612@naver.com (M.L.); sinyunchan@naver.com (Y.S.) \\ 2 Department of Mechanical Engineering, Chosun University, 303 Pilmun-daero, Dong-gu, \\ Gwangju 501-759, Korea \\ * Correspondence: hhcho@chosun.ac.kr
}

Received: 9 January 2020; Accepted: 29 March 2020; Published: 4 April 2020

check for

\begin{abstract}
This study experimentally investigated the performance characteristics of water and MWCNT $/ \mathrm{Fe}_{3} \mathrm{O}_{4}$ binary nanofluid as a working fluid in a flat plate and vacuum tube solar collectors. As a result, the highest efficiency was $80.3 \%$ when 0.005 vol. $\%$ MWCNT/0.01 vol. $\% \mathrm{Fe}_{3} \mathrm{O}_{4}$ binary nanofluid was applied to the flat plate solar collector, which was a $17.6 \%$ increase in efficiency, compared to that when water was used. In the case of the vacuum tube solar collector, the highest efficiency was $79.8 \%$, which was $24.9 \%$ higher than when water was applied. Besides, when the mass flux of MWCNT/ $\mathrm{Fe}_{3} \mathrm{O}_{4}$ binary nanofluid was changed from 420 to $598 \mathrm{~kg} / \mathrm{s} \cdot \mathrm{m}^{2}$, the maximum efficiencies of the flat plate and vacuum tube solar collectors were increased by $7.8 \%$ and $8.3 \%$, respectively. When the MWCNT/ $/ \mathrm{Fe}_{3} \mathrm{O}_{4}$ binary nanofluid was applied to the vacuum tube solar collector, the efficiency improvement was much more significant, and the high performance could be maintained for wide operating conditions, compared with the flat plate solar collector.
\end{abstract}

Keywords: flat plate solar collector (FPSC); vacuum tube solar collector (VTSC); binary nanofluid; thermal efficiency; multi-walled carbon nanotube (MWCNT); $\mathrm{Fe}_{3} \mathrm{O}_{4}$ ferrofluid

\section{Introduction}

As the global climate and $\mathrm{PM}_{2.5}$ problems have become an issue around the world, major developed countries worldwide are implementing green energy policies. In 2001, the European Union introduced national targets for power and transportation in 2010, through the Green Electricity Directive, and the Biofuels Directive [1]. In addition, the Directive for Renewable Energy was enacted to promote the development and distribution of renewable energy in 2009, and the country targets for renewable energy policies will become legally binding in 2020. As energy policies that increase the use of renewable energy in the world are established and implemented, renewable energy-related industries are growing rapidly.

The global supply of renewable energy is growing steadily, and as efforts are made to expand the amount of renewable energy in each country, and with the increase of the price competitiveness of renewable energy, continuous market growth is expected. In addition, like solar energy and wind energy account for about $85 \%$ of the new installed capacity, new facilities related to these energies are expected to be expanded in China, the United States, and India, which use them as the primary renewable energy sources. Accordingly, various studies are being actively conducted by the government, universities, and research institutes to improve the utilization and efficiency of renewable energy systems. 
'Renewable energy' is a complex expression of new energy and renewable energy, and it refers to energy used by converting renewable energy, such as sunlight, water, wind, ocean, and biomass to replace fossil fuel. Among them, solar thermal energy means using the energy that is emitted from the sun that reaches the earth. The advantages of solar thermal energy are an infinite resource for as long as the sun is emitting light, a pollution-free source of energy without greenhouse gas emissions, less regional biases, and a high possibility for various applications and uses. However, it has the disadvantages consist of high initial installation costs. Additionally, the cost of heating obtained against the investment is generally low. Recently, interest in solar thermal energy is increasing, as the depletion of fossil fuels and environmental problems has become a big issue.

In the history of using solar energy, from the 7th century B.C., a fire was started by using magnifiers or convex lenses, which were used to focus the sun's rays. In addition, in ancient Greece and Rome in the 3rd century B.C., solar energy was collected using reflectors to light torches used for religious purposes. In the early steps in the use of solar collectors, solar energy-based solar collectors began in the 1900s, with black painted tanks on the roof. The flat plate solar collector used to make low-pressure steam using solar heat was employed in Florida, and Southern California in the 1920s and interest in solar heating in North America rose in the aftermath of the 1960s. In particular, after the oil shock that hit the world in 1973, the interest in solar heat has increased.

To increase the cost-effectiveness of solar collectors by enhancing their efficiency, Jouybari et al. [2] experimentally evaluated the performance of the flat plate solar collector when porous channels filled with $\mathrm{SiO}_{2} /$ water nanofluids were applied. The thermal efficiency increased by $6 \%-8 \%$ by increasing the volume concentration. Azad [3] experimentally investigated the thermal performance of a flat plate solar collector with multiple heat pipes and reported that by increasing the number of heat pipes, the efficiency of the flat plate solar collector could be enhanced. In addition, Gunjo et al. [4] conducted experiments and analysis on exergy and energy in a new tubular solar collector. The developed simulation models predicted the exit temperature, absorption plate temperature, energy efficiency, and heat loss parameter within the maximum error of $9 \%$, and the thermal efficiency of the manufactured tubular solar collector was $71 \%$. Gao et al. [5] presented experimentally that the heat pipe type flat plate solar collector showed a large variation in thermal characteristics depending on the gradient angle, with a maximum efficiency of $74.3 \%$, which was superior to those of other similar designed ones. Even though there were many attempts to increase the effectiveness of the solar collector by the change of structure, the method of structural change in the solar collector has technical limitations. It has the disadvantage of being more expensive than the conventional solar collector.

Therefore, research on the improvement of the thermal and optical properties of the working fluid by using various nanofluids as a way to improve efficiency in conventional solar collectors has been actively conducted. To enhance the effectiveness of solar collectors, many studies have been undertaken by evaluating the heat loss parameter and flow analysis according to the arrangement of solar collectors [6,7]. Yousefi et al. [8] and Said et al. [9] experimentally presented the thermal performance of the flat plate solar collector by using $\mathrm{Al}_{2} \mathrm{O}_{3}$ nanofluid, and reported that the thermal efficiency was improved over $20 \%$ that of water. They also found that the addition of surfactants into an $\mathrm{Al}_{2} \mathrm{O}_{3}$ nanofluid significantly increased the effectiveness of the solar collector. In the study of MWCNT nanofluid [10], the effect of concentration and mass flux on the efficiency of the flat plate solar collector was investigated experimentally. As a result, the heat gain parameter was improved by $27.4 \%$ and $45.8 \%$, respectively, compared to the essential fluid, when the concentration of MWCNT nanofluid was $0.2 \mathrm{wt} . \%$, and $0.4 \mathrm{wt} . \%$, and the heat loss parameter decreased by $0.36 \%$ at $0.2 \mathrm{wt} . \%$.

In comparison, it increased by $65.5 \%$ at $0.4 \mathrm{wt} . \%$. Sharafeldin and Grof [11] reported that the efficiency of the flat plate solar collector was proportionally increased with an increase of the mass flux of $\mathrm{CeO}_{2}$ nanofluid, and the optimum concentration of $\mathrm{CeO}_{2}$ nanofluid was 0.0333 vol.\%. In the previous study of applying nanofluids to the vacuum tube solar collector, Sharafeldin and Grof $[12,13]$ used $\mathrm{WO}_{3} /$ water and $\mathrm{CeO}_{2}$ /water nanofluids in the vacuum tube solar collector. They showed that the 
efficiency enhancement of the vacuum tube solar collector was $19.3 \%$ and $34.8 \%$ for $\mathrm{WO}_{3} / \mathrm{Water}$ and $\mathrm{CeO}_{2} /$ water nanofluids, compared to water alone.

Further studies on the performance of the solar collector, and reviews on the performance of the solar collector with various nanofluids were also carried out. Li et al. [14] experimentally analyzed the water-based on $\mathrm{Al}_{2} \mathrm{O}_{3}, \mathrm{ZnO}$, and $\mathrm{MgO}$ nanofluid as a working fluid in a tubular solar collector. As a result, 0.2 vol. $\% \mathrm{ZnO}$ nanofluid showed the best performance. Tong et al. $[15,16]$ compared the performance of the heat pipe and U-tube collector, and they reported that the heat transfer coefficient in the U-tube solar collector at the $0.24 \mathrm{vol} . \%$ MWCNT nanofluid was about $8 \%$ higher than that of using water. Prasher et al. [17] theoretically compared the performance of the direct absorption solar collector (DASC) and the flat plate solar collector using Al nanofluid, and reported that the absorption in $\mathrm{Al}$ nanofluid was nine times greater than that of pure water.

Moreover, the DASC using Al nanofluid presented 10\% higher efficiency than that of the flat plate solar collector. Taylor et al. $[18,19]$ investigated the effectiveness of the concentrating parabolic solar collector using $\mathrm{Al}_{2} \mathrm{O}_{3}$ nanofluid based on Therminol VP-1 and presented a $10 \%$ higher efficiency than water. Furthermore, Kang et al. [20] reported that the effectiveness of flat plate and U-tube solar collectors of $\mathrm{Al}_{2} \mathrm{O}_{3}$ nanofluid was $14.8 \%$ and $10.7 \%$ higher than that of water, respectively. With the use of coal, $\mathrm{CO}_{2}$ generation, and $\mathrm{SO}_{2}$ production could reduce the solar collector efficiency, when 50 flat plate solar collectors using $\mathrm{Al}_{2} \mathrm{O}_{3}$ nanofluid were used for one year. Otanicar and Golden [21] compared the environmental and economic impacts of using nanofluids to enhance solar collector efficiency as compared to conventional solar collectors in the domestic hot water system. Their results showed that for the current cost of nanoparticles, the nanofluid based solar collector has a slightly more extended payback period but at the end of its useful life has the same economic savings in a conventional solar collector. Previous studies show that the efficiency of the solar collector is greatly improved when various nanofluids are used as a working fluid. Presently, some nanofluids are more expensive than the existing working fluids. On the other hand, when the long-term use of nanofluid and dispersion stability are secured, the price of nanofluid can be dramatically reduced through the mass production system.

Recent studies have seriously focused on the use of working fluids in which the dispersion stability, thermal performance, and optical properties of a single nanofluid are ensured. Therefore, it is necessary to investigate the physical and chemical properties of hybrid nanofluid by studying binary nanofluids for improving the limit of single component nanofluids in the solar collector and improving the thermal properties of the working fluid. Menbari et al. [22] studied the dispersion stability, viscosity, and extinction coefficient of $\mathrm{Al}_{2} \mathrm{O}_{3}-\mathrm{CuO} /$ water binary nanofluid experimentally. Experimental results showed that the optimal $\mathrm{pH}$ of the $\mathrm{Al}_{2} \mathrm{O}_{3}-\mathrm{CuO}$ /water binary nanofluid was $\mathrm{pH}=7.5-8.5$, and the increase of the volume fraction of nanoparticles improved the extinction coefficient and absorbance spectrum of nanofluid. Zeng and Xuan [23] showed experimentally that the photo-thermal efficiency of MWCNT-SiO $/$ Ag binary nanofluid was more efficient than that of MWCNT and $\mathrm{SiO}_{2} / \mathrm{Ag}$ nanofluids. Besides, the photoconversion efficiency increased with temperature in all nanofluids. Menbari et al. [24] studied the absorption and thermal conductivities of various binary nanofluids. Since $\mathrm{Al}_{2} \mathrm{O}_{3}$ nanoparticle had high thermal capacities but low absorption spectra compared to those of $\mathrm{CuO}$ nanoparticle, the heat capacity, solar absorption, and heat and optical efficiencies of the solar collector could be improved when they were used as a binary nanofluid. Dalkılıç et al. [25] experimentally found that the thermal conductivity of 0.8 vol. $\% \mathrm{CNT} / 0.2$ vol. $\% \mathrm{SiO}_{2}$ binary nanofluid was $26.3 \%$ higher than that of water.

In this study, $\mathrm{MWCNT} / \mathrm{Fe}_{3} \mathrm{O}_{4}$ binary nanofluid was applied as a working fluid for the flat plate and vacuum tube solar collectors because MWCNT has high thermal conductivity and $\mathrm{Fe}_{3} \mathrm{O}_{4}$ nanofluid has a high possibility of increase of optical properties because of its strong absorption in the near-infrared. Moreover, $\mathrm{Fe}_{3} \mathrm{O}_{4}$ nanofluid is a magnetic nanofluid and can be controlled by the change of strength and direction of the magnetic field. That can improve the thermophysical properties of $\mathrm{Fe}_{3} \mathrm{O}_{4}$ nanofluid compared to essential fluids such as ethylene glycol and water. Fu et al. [26] investigated the turbulent 
heat transfer of $\mathrm{Fe}_{3} \mathrm{O}_{4} /$ Ethylene glycol. By increasing the $\mathrm{pH}$ of suspended solids, nanoparticles with highly refined particles did not improve the heat transfer performance of nanofluids.

Moreover, the convective heat transfer coefficient of the nanofluid was $7 \%$ lower than that of the reference solution. Qu et al. [27] presented results showing that the CuO-MWCNT binary nanofluid compounds significantly improved the absorption of solar energy spectra compared to single $\mathrm{CuO}$ or MWCNT nanofluid. Shi et al. [28] found that the thermal conductivity of $0.25 \mathrm{vol} . \%$ $\mathrm{Fe}_{3} \mathrm{O}_{4} / \mathrm{CNT}$ binary nanofluid was more sensitive to temperature change than that $0.25 \mathrm{vol} \%$ $\mathrm{Fe}_{3} \mathrm{O}_{4}$ nanofluid, which is closely related to hydrogen bonding, because it accelerates heat transfer. Harandi et al. [29] conducted an empirical study on the effect of temperature and concentration on the thermal conductivity off-MWCNTs- $\mathrm{Fe}_{3} \mathrm{O}_{4} / \mathrm{EG}$ binary nanofluid. They found that the thermal conductivity was improved with increasing intensity and temperature. In addition, the thermal conductivity off-MWCNTs- $\mathrm{Fe}_{3} \mathrm{O}_{4} / \mathrm{EG}$ binary nanofluid was increased by $30 \%$. In addition, Jung et al. [30] found that the thermal conductivity increased with the concentration of binary nanofluid, and dispersion stability was the key factor in increasing the thermal conductivity of nanofluid.

When a nanofluid is applied as a working fluid to a solar collector, it limits the dispersion stability and the concentration with maximum efficiency according to nanofluid. Since each type of nanofluid are different in characteristics. Therefore, it is necessary to analyze the efficiency characteristics according to various conditions and nanofluids to improve the utilization of the solar collector. Furthermore, a detailed study on the improvement of the efficiency of the solar collector is essential. Nanofluids have been found to improve thermal conductivity and can improve optical absorption, but stability is still an issue. Based on the subject, as mentioned earlier, it has led the researchers to focus on binary nanofluids in the heating system. However, an experimental study on the performance of the solar collector takes a long time and is hard to carry out continuously due to unexpected weather.

Thus, it is difficult to experimentally summarize and define the characteristics of the solar collector, depending on the working fluid. Additionally, many types of research on the efficiency improvement in the solar collector, according to the working fluid, are currently being conducted. The experiment information in the open literature using multi-components nanofluid with more than two components is still in the early stage. In particular, $\mathrm{MWCNT} / \mathrm{Fe}_{3} \mathrm{O}_{4}$ binary nanofluid, which is a mixture of MWCNT and $\mathrm{Fe}_{3} \mathrm{O}_{4}$ nanofluid, has a high possibility of improving the thermal efficiency of the solar collector because MWCNT nanofluid has the highest capacity when it is applied to the conventional solar collector. Moreover, the $\mathrm{Fe}_{3} \mathrm{O}_{4}$ nanofluid, when it is used as a working fluid in the flat plate and vacuum tube solar collectors, has high potential to increase efficiency due to its substantial photon absorption cross-section. While the magnetic properties of $\mathrm{Fe}_{3} \mathrm{O}_{4}$ have been exploited to improve convective heat transfer in previous studies, the main advantage for the solar collector is presumably in its absorption in the near-infrared. In this study, the performance characteristics of flat plate and vacuum tube solar collectors were analyzed according to the concentration and mass flux of $\mathrm{MWNCT} / \mathrm{Fe}_{3} \mathrm{O}_{4}$ binary nanofluid for variable operating conditions under without magnetic field, and the results compared with those when water was used. Four cases of $\mathrm{MWNCT} / \mathrm{Fe}_{3} \mathrm{O}_{4}$ binary nanofluids with different mixing ratios were used to compare the efficiency of solar collectors depending on the mixing ration of $\mathrm{MWNCT} / \mathrm{Fe}_{3} \mathrm{O}_{4}$ binary nanofluid.

\section{Experimental Setup and Procedure}

\subsection{Experimental Setup}

Solar collectors are facilities that are designed to effectively collect and utilize solar energy by converting it to thermal energy. Figure 1a shows the flat plate solar collector used in this study. The flat plate solar collector consists of a transparent body, absorption plate, heat pipe, and insulation to prevent heat loss to the surroundings. The flat plate solar collector is the most commonly used solar collector in the world and has a flat surface area and solar energy absorption area with the same incident area of solar energy. Figure $1 \mathrm{~b}$ shows the vacuum tube solar collector used in this experiment. 
The vacuum tube solar collector consists of inner and outer glass, a vacuum layer, an absorption plate, and a coating layer. The vacuum tube solar collector is designed to reduce the heat loss from the absorber tube by removing inside air in the solar collector and blocking heat transfer to the outside by convection. The experiment was conducted at Chosun University (latitude: $35.1427^{\circ} \mathrm{N}$, longitude: $126.9347^{\circ} \mathrm{E}$ ) in Gwangju, Korea, and was performed from 10:00 a.m. to 5:00 p.m. during the winter season. The efficiency of solar collector was calculated at a step of one day except for cloudy days. Before obtaining the experimental data, 30 minutes of pre-operation was carried out to maintain the constant operating condition in the solar collector. In this study, the efficiency of the flat plate and vacuum tube solar collectors according to the concentration of $\mathrm{MWCNT} / \mathrm{Fe}_{3} \mathrm{O}_{4}$ binary nanofluid as a working fluid was investigated and analyzed. Performance tests with two solar collectors were carried out simultaneously in the same place, to compare the performance between the flat plate and the vacuum tube solar collector.

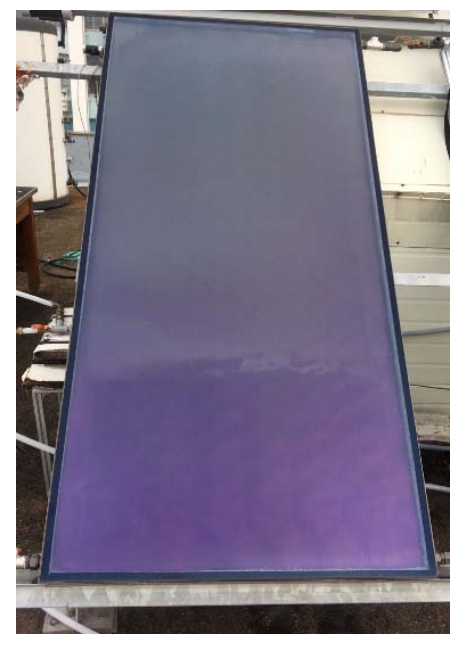

(a)

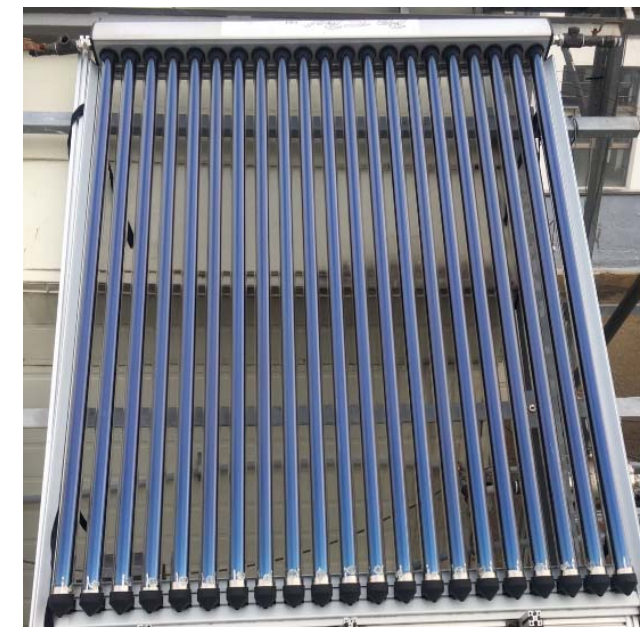

(b)

Figure 1. The flat plate and vacuum tube solar collectors used in this study. (a) Flat plate solar collector; (b) Vacuum tube solar collector.

Figure 2 shows a schematic of the solar collecting experiment setup. The working fluid enters the solar collector through the pump, passes through the solar collector, and flows into the water tank with a capacity of $100 \mathrm{~L}$, then exchanges the heat and circulates in the system again. In this study, the heat storage tank was used according to the capacity of the solar collector system. The heat exchanger was installed inside the heat storage tank, and it was connected to the constant temperature bath to control the inlet temperature of working fluid in the solar collector.

The temperature and mass flow of working fluid in the constant temperature bath was preciously controlled to remove the heat in the heat storage tank. T-type thermocouples and pressure gauges are installed to measure the temperature and pressure in the inlet and outlet of the solar collector, and a solar radiation meter is installed at the top of the solar collector to measure the solar radiation on the surface of the solar collector. The flow rate of the working fluid circulating in the solar collector is measured using a flow meter, and all data are collected using a data logger. Table 1 lists the detailed specifications of the measuring devices used in this experiment. 


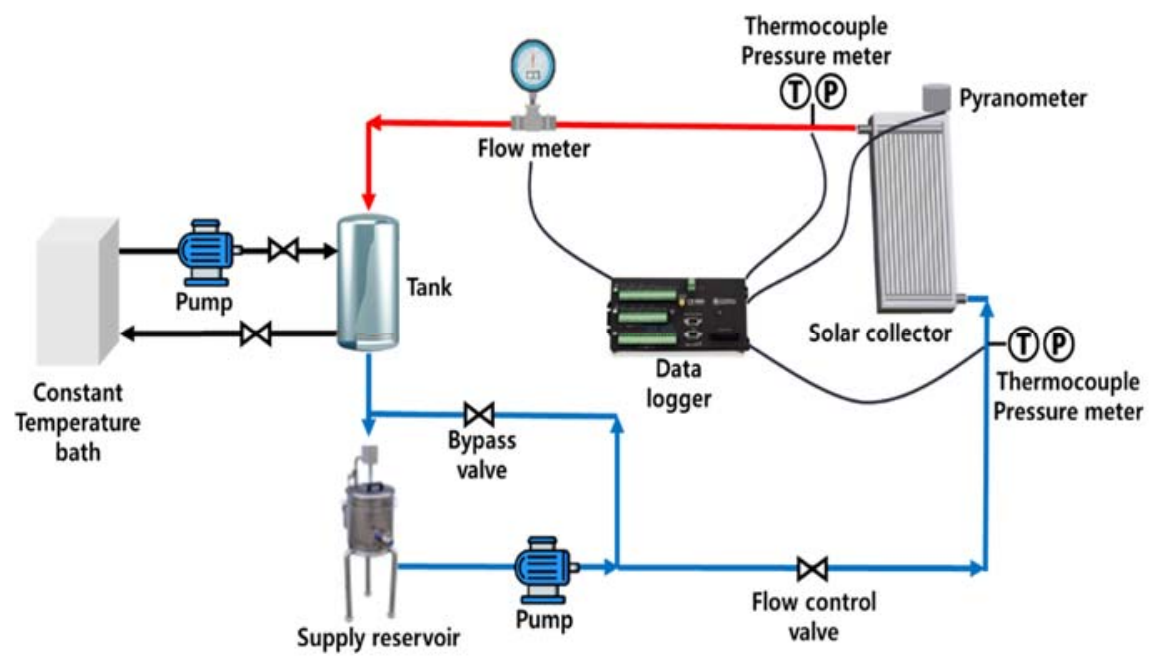

Figure 2. Schematics of the solar collector system.

Table 1. Specifications of the experimental equipment.

\begin{tabular}{ccc}
\hline Test Setup & Item & Specification \\
\hline \multirow{2}{*}{ Thermocouple } & Type & T-type \\
& Range & $-200{ }^{\circ} \mathrm{C}-300{ }^{\circ} \mathrm{C}$ \\
& Standard limits of error & $0.75 \%$ \\
\hline \multirow{2}{*}{ Solar power meter } & Type & $\mathrm{CR}-100$ \\
& Temperature & $-10^{\circ} \mathrm{C}-70{ }^{\circ} \mathrm{C}$ \\
& Range & $0-1500 \mathrm{~W} / \mathrm{m}^{2}$ \\
Flowmeter & Accuracy & $5 \%$ \\
& Model & $\mathrm{E}-\mathrm{MAG}-1$ \\
& Max flow rate & $1.4 \mathrm{~m} / \mathrm{h}$ \\
& Accuracy & $\pm 0.5 \%$ \\
\hline \multirow{2}{*}{ Data acquisition system } & Model & $\mathrm{MX} 100($ Yokogawa Inc. $)$ \\
& Measurement interval & $100 \mathrm{~ms}(\mathrm{shortest})$ \\
& Accuracy & $\pm 0.05 \%$ \\
\hline
\end{tabular}

\subsection{Manufacturing the $\mathrm{MWCNT} / \mathrm{Fe}_{3} \mathrm{O}_{4}$ Binary Nanofluid}

The MWCNT/ $/ \mathrm{Fe}_{3} \mathrm{O}_{4}$ binary nanofluid used in this study was prepared by adding MWCNT and $\mathrm{Fe}_{3} \mathrm{O}_{4}$ nanoparticles into the water as a base fluid with various concentrations. Since the use of more than $20 \mathrm{~L}$ of nanofluids is required in the solar collector system, a large volume capacity nanofluid was needed. To make a large capacity of nanofluid, the two-step manufacturing method was used, which is to disperse the nanoparticles into a base fluid (water). The dispersion process was performed for 8 hours by using a continuous circulating ultrasonic dispersing device. The sizes of the MWCNT and $\mathrm{Fe}_{3} \mathrm{O}_{4}$ nanoparticles were 20 and $30 \mathrm{~nm}$, respectively. Figures 3 and 4 show Transmission Electron Microscopy (TEM) photographs of the MWCNT/ $\mathrm{Fe}_{3} \mathrm{O}_{4}$ nanoparticles and images of the MWCNT/ $/ \mathrm{Fe}_{3} \mathrm{O}_{4}$ binary nanofluid according to concentration. Figure 3 shows that the thread-like MWCNT nanoparticles and spherical $\mathrm{Fe}_{3} \mathrm{O}_{4}$ nanoparticles are well mixed. Figure 4 shows that the color of the MWCNT/ $\mathrm{Fe}_{3} \mathrm{O}_{4}$ nanofluid with the concentration is dark and is not visible to the naked eye. The color darkens as the concentration increases. Generally, black nanofluid is good at absorbing light; thus, it has advantages to use as a working fluid in a direct absorption solar collector or just solar collector. 


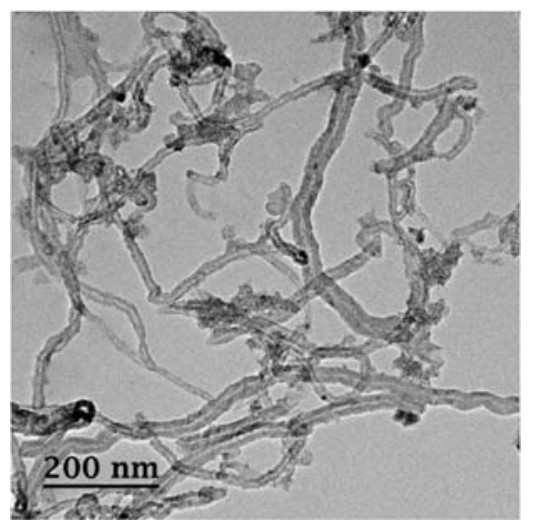

Figure 3. TEM image of an $\mathrm{MWCNT} / \mathrm{Fe}_{3} \mathrm{O}_{4}$ nanoparticle.

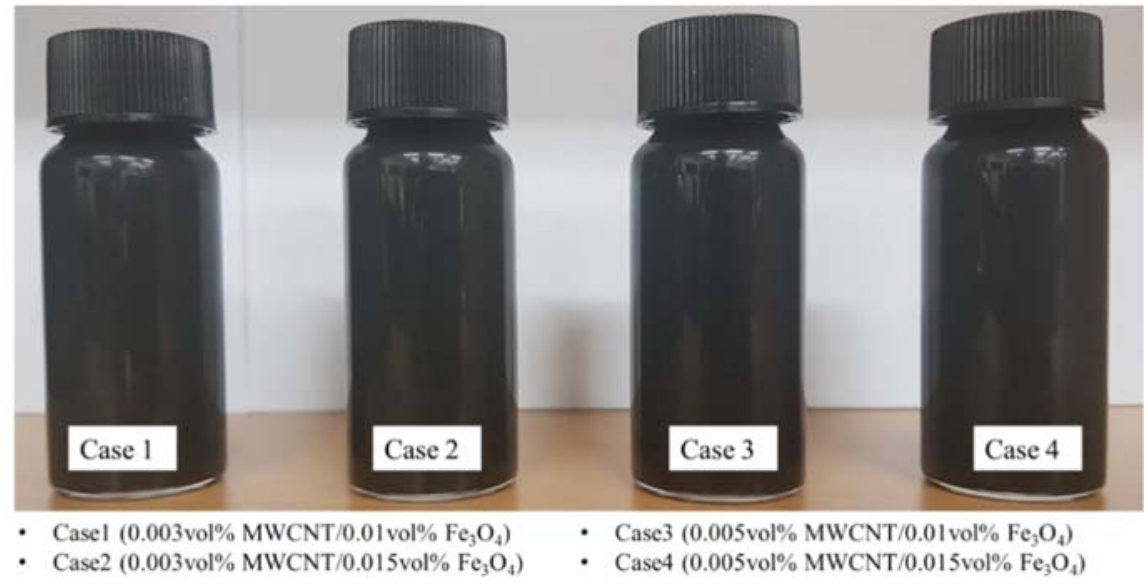

Figure 4. Pictures of four MWCNT/ $\mathrm{Fe}_{3} \mathrm{O}_{4}$ binary nanofluids.

To apply nanofluid in the solar collector as a working fluid, the dispersion stability of the nanofluid must be secured. The dispersion stability of the nanofluid that was fabricated in this study was checked by two methods: one is visual confirmation, and the other is by measuring the zeta potential value. First, $\mathrm{Fe}_{3} \mathrm{O}_{4}$ and MWCNT nanofluids prepared for visual inspection were observed for two weeks, and all nanofluids were observed without precipitation. Generally, it can be judged that the nanofluid is stable if the absolute value of the zeta potential is more than 30 . The zeta potential for the MWCNT/ $/ \mathrm{Fe}_{3} \mathrm{O}_{4}$ binary nanofluid used in this experiment was ranged from -21 to $-47 \mathrm{mV}$, which was the most stable condition to use as a working fluid in the solar collector system. Especially, the zeta potential of Case3 (0.005vol.\% MWCNT/0.01vol.\% $\mathrm{Fe}_{3} \mathrm{O}_{4}$ ) was -27 to $40 \mathrm{mV}$.

\subsection{Experimental Procedure and Efficiency Calculation}

In this experiment, the efficiencies of the flat plate and vacuum tube solar collectors were compared according to the concentration of nanofluid when water and the $\mathrm{MWCNT} / \mathrm{Fe}_{3} \mathrm{O}_{4}$ binary nanofluid was used. Table 2 presents detailed specifications of the flat plate and the vacuum tube solar collector. The gross areas of the flat plate and the vacuum tube solar collector are 2 and $2.37 \mathrm{~m}^{2}$, respectively; however, the effective area that can collect the heat from sunlight is almost similar for the two solar collectors. In addition, other design factors of the two solar collectors were set similarly, in order to investigate the efficiency and to operate characteristics depending on the type of solar collector. 
Table 2. Specifications of the flat plate and vacuum tube solar collectors.

\begin{tabular}{ccc}
\hline Parameter & Flat Plate Solar Collector & Vacuum Tube Solar Collector \\
\hline Collector length $(\mathrm{mm})$ & 2000 & 1445 \\
Collector width $(\mathrm{mm})$ & 1000 & 1640 \\
Gross area $\left(\mathrm{m}^{2}\right)$ & 2.00 & 2.37 \\
Weight $(\mathrm{kg})$ & 36 & 51.5 \\
Riser tube material & Copper & Copper \\
Inner diameter of pipes $(\mathrm{mm})$ & 8 & 10 \\
Outer diameter of pipes $(\mathrm{mm})$ & 8.8 & 15 \\
Absorptivity of absorber coating & 0.95 & 0.95 \\
\hline
\end{tabular}

Table 3 shows the experimental conditions of this study. The first working fluids in this study were water and MWCNT/ $/ \mathrm{Fe}_{3} \mathrm{O}_{4}$ binary nanofluid. The mixing concentrations of $\mathrm{MWCNT} / \mathrm{Fe}_{3} \mathrm{O}_{4}$ binary nanofluid were set up by using the maximum efficiency for each solar collector and each nanofluid. In the study of Kang et al. [31], the optimum concentration was 0.005 vol.\% for MWCNT nanofluid, and 0.015 vol.\% for $\mathrm{Fe}_{3} \mathrm{O}_{4}$ nanofluid in the solar collector, respectively. Many previous studies reported that the use of high concentrations of nanofluid as a working fluid could reduce heat transfer performance due to the decrease in the dispersion stability of the nanofluid. Therefore, the system efficiency was no longer increased. To make the binary nanofluid, the dispersion stability of the binary nanofluid should be considered, thus the lower concentrations from the optimum efficiency $(0.003 \mathrm{vol} . \%$ for MWCNT, 0.01 vol.\% for $\mathrm{Fe}_{3} \mathrm{O}_{4}$ nanofluid) were also used for binary nanofluid. In this study, four cases of MWCNT/ $\mathrm{Fe}_{3} \mathrm{O}_{4}$ binary nanofluid were used; Case1 is 0.003 vol.\% MWCNT/0.01 vol. $\% \mathrm{Fe}_{3} \mathrm{O}_{4}$ binary nanofluid, Case2 is 0.003 vol. \% MWCNT/0.015 vol. $\% \mathrm{Fe}_{3} \mathrm{O}_{4}$ binary nanofluid, Case3 is 0.005 vol.\% MWCNT/0.01 vol. $\% \mathrm{Fe}_{3} \mathrm{O}_{4}$ binary nanofluid and Case4 is 0.005 vol.\% MWCNT/0.015 vol. $\% \mathrm{Fe}_{3} \mathrm{O}_{4}$ binary nanofluid, respectively. The experiment was conducted from 10 a.m. to 5 p.m. during the winter season, and the measured range of solar radiation was $100-800 \mathrm{~W} / \mathrm{m}^{2}$. The inlet temperature of the working fluid in the solar collector was measured as $10^{\circ} \mathrm{C}-12{ }^{\circ} \mathrm{C}$. Two kinds of mass fluxes of working fluid were used: 420 and $598 \mathrm{~kg} / \mathrm{s} \cdot \mathrm{m}^{2}$. The efficiency of a solar collector was calculated at a step of one day except for cloudy days. Before obtaining the experimental data, 30 minutes of pre-operation was carried out to maintain the constant working condition of the solar collector. In this study, to present the improvement of efficiency in the solar collector according to operating conditions, the effectiveness of the flat plate solar collector was used as the base condition when the water with a mass flux of $420 \mathrm{~kg} / \mathrm{s} \cdot \mathrm{m}^{2}$ was used. The experiment was carried out to compare and analyze the efficiency by applying water and $\mathrm{MWCNT} / \mathrm{Fe}_{3} \mathrm{O}_{4}$ binary nanofluid to the flat plate and vacuum tube solar collector. Moreover, each efficiency was compared with the operating conditions. The useful heat of the working fluid in the solar collector is the same as heat flux absorbed by the absorber. It can be expressed as Equation (1):

$$
Q_{u}=\dot{m} c_{p}\left(T_{o}-T_{i}\right)
$$

where, $\dot{m}$ is the mass flow rate of the working fluid, $c_{p}$ is the specific heat of the working fluid, and $T_{o}$ and $T_{i}$ are the outlet and inlet temperatures, respectively, of the working fluid in the solar collector. 
Table 3. Experimental conditions.

\begin{tabular}{|c|c|c|}
\hline \multicolumn{2}{|c|}{ Item } & Specification \\
\hline \multicolumn{2}{|c|}{ Type of working fluid } & Water, $\mathrm{MWCNT} / \mathrm{Fe}_{3} \mathrm{O}_{4}$ binary nanofluid \\
\hline \multicolumn{2}{|c|}{$\begin{array}{l}\text { Concentration of } \mathrm{MWCNT} / \mathrm{Fe}_{3} \mathrm{O}_{4} \text { binary } \\
\text { nanofluid (vol. } \% \text { ) }\end{array}$} & $\begin{array}{l}\text { Case1 (0.003vol.\% MWCNT/0.01vol.\% } \mathrm{Fe}_{3} \mathrm{O}_{4} \text { ) } \\
\left.\text { Case2 (0.003vol.\% MWCNT/0.015vol.\% } \mathrm{Fe}_{3} \mathrm{O}_{4}\right) \\
\text { Case3 (0.005vol.\% MWCNT/0.01vol.\% } \mathrm{Fe}_{3} \mathrm{O}_{4} \text { ) } \\
\text { Case4 (0.005vol.\% MWCNT/0.015vol.\% } \mathrm{Fe}_{3} \mathrm{O}_{4} \text { ) }\end{array}$ \\
\hline \multicolumn{2}{|c|}{ Experiment time $(\mathrm{h})$} & 10:00-16:00 \\
\hline \multicolumn{2}{|c|}{ Solar radiation $\left(\mathrm{W} / \mathrm{m}^{2}\right)$} & $100-850$ \\
\hline \multirow{2}{*}{ Working fluid } & Inlet temp. $\left({ }^{\circ} \mathrm{C}\right)$ & $10-12$ \\
\hline & Mass flux $\left(\mathrm{kg} / \mathrm{s} \cdot \mathrm{m}^{2}\right)$ & 420,598 \\
\hline
\end{tabular}

MWCNT nanoparticles have a density, specific heat, and thermal conductivity of $1350 \mathrm{~kg} / \mathrm{m}^{3}$, $650 \mathrm{~J} / \mathrm{kg} \cdot \mathrm{K}$, and $1500 \mathrm{~W} / \mathrm{m} \cdot \mathrm{K}$, respectively. In the case of $\mathrm{Fe}_{3} \mathrm{O}_{4}$ nanoparticle, the density, specific heat, and thermal conductivity are $5200 \mathrm{~kg} / \mathrm{m}^{3}, 670 \mathrm{~J} / \mathrm{kg} \cdot \mathrm{K}$, and $80.4 \mathrm{~W} / \mathrm{m} \cdot \mathrm{K}$, respectively. The density and specific heat of the MWCNT and $\mathrm{Fe}_{3} \mathrm{O}_{4}$ nanofluid used in this study can be expressed by Equations (2) and (3) [32,33]:

$$
\begin{gathered}
\rho_{n f}=\left(1-\phi_{v}\right) \rho_{b f}+\phi_{v} \rho_{n p} \\
c_{p, n f}=\frac{\left(1-\phi_{v}\right) \rho_{b f} c_{p, b f}+\phi_{v} c_{p, n p}}{\rho_{n f}}
\end{gathered}
$$

where, $\rho_{b f}$ is the density of the working fluid, and $\varphi$ is the volume fraction of the working fluid.

The density and specific heat of the $\mathrm{MWCNT} / \mathrm{Fe}_{3} \mathrm{O}_{4}$ binary nanofluid can be calculated using Equations (4) and (5), which are defined by Hemmat et al. [34]:

$$
\begin{gathered}
\rho_{n p}=\frac{\phi_{1} \cdot \rho_{n p 1}+\phi_{2} \cdot \rho_{n p 2}}{\phi_{1}+\phi_{2}} \\
c_{p, n p}=\frac{\phi_{1} \cdot \rho_{n p 1} \cdot c_{p, n p 1}+\phi_{2} \cdot \rho_{n p 2} \cdot c_{p, n p 2}}{\rho_{n p} \cdot\left(\phi_{1}+\phi_{2}\right)}
\end{gathered}
$$

Table 4 shows the density and specific heat of the water and the MWCNT/ $/ \mathrm{Fe}_{3} \mathrm{O}_{4}$ binary nanofluid.

Table 4. Thermophysical properties of the working fluid.

\begin{tabular}{cccc}
\hline Case & $\boldsymbol{\varphi}(\mathbf{v o l .} \%)$ & $\rho_{\text {nf }}\left(\mathbf{k g} / \mathbf{m}^{3}\right)$ & $c_{p, n f}(\mathbf{J} / \mathbf{k g} \cdot \mathbf{K})$ \\
\hline Water & - & 1011 & 4023 \\
\hline Case1 & 0.013 & 1039 & 4006 \\
\hline Case2 & 0.018 & 1060 & 3923 \\
\hline Case3 & 0.015 & 1037 & 4007 \\
\hline Case4 & 0.020 & 1058 & 3924 \\
\hline
\end{tabular}

The efficiency of the solar collector can also be calculated from Equation (6):

$$
\eta=\frac{Q_{u}}{A_{c} G}=F_{R}(\tau \alpha)-F_{R} U_{T} \frac{T_{i}-T_{a}}{G}
$$

where, $F_{R}(\tau \alpha)$ is the heat gain parameter of the collector, and $F_{R} U_{L}$ is the heat loss parameter of the solar collector. 
The uncertainty of solar collector efficiency is determined by the specific error of the flow meter, thermometer, solar irradiance, and specific heat of nanofluid. The uncertainty of the solar collector efficiency is given by Moffat [35] and can be expressed as Equation (7):

$$
\frac{\delta \eta}{\eta}=\left[\left(\frac{\delta m}{m}\right)^{2}+\left(\frac{\delta\left(T_{o}-T_{i}\right)}{T_{o}-T_{i}}\right)^{2}+\left(\frac{\delta c_{p}}{c_{p}}\right)^{2}+\left(\frac{\delta G}{G}\right)^{2}\right]^{0.5}
$$

From the above equation, the maximum error of the mass flow rate was calculated as in Equation (8):

$$
\frac{\delta m}{m} \leq 0.5 \%
$$

In addition, the maximum error of temperature was calculated, as shown in Equation (9):

$$
\frac{\delta\left(T_{o}-T_{i}\right)}{T_{o}-T_{i}} \leq\left[\left(\frac{\delta T_{o}}{T_{o}}\right)^{2}+\left(\frac{\delta T_{i}}{T_{i}}\right)^{2}\right]^{0.5}=\left[\left(\frac{0.2}{18}\right)^{2}+\left(\frac{0.2}{12}\right)^{2}\right]^{0.5}=2 \%
$$

The maximum error of insolation and nanofluid specific heat was calculated as in Equations (10) and (11):

$$
\begin{gathered}
\frac{\delta G}{G} \leq 5 \% \\
\frac{\delta c_{p}}{c_{p}} \leq 1.22 \%
\end{gathered}
$$

Therefore, the maximum error of the solar collector efficiency used in this study can be expressed as Equation (12):

$$
\frac{\delta \eta}{\eta}=\left[(0.5 \%)^{2}+(2 \%)^{2}+(1.22 \%)^{2}+(5 \%)^{2}\right]^{0.5} \leq 5.54 \%
$$

In this study, the measurement errors of the flow meter, thermometer, solar irradiance, and nanofluid were $0.5 \%, 2 \%, 5 \%$, and $1.22 \%$, respectively, and the uncertainty of solar collector efficiency was within $5.54 \%$.

\section{Results and Discussion}

In this study, water and $\mathrm{MWCNT} / \mathrm{Fe}_{3} \mathrm{O}_{4}$ binary nanofluid were applied to the flat plate and vacuum tube solar collector for various operating conditions. In the case of $\mathrm{MWCNT} / \mathrm{Fe}_{3} \mathrm{O}_{4}$ binary nanofluid, four cases of MWCNT/ $/ \mathrm{Fe}_{3} \mathrm{O}_{4}$ binary nanofluids were used. Figure $5 \mathrm{a}$ shows the efficiency of the solar collector when water and $\mathrm{MWCNT} / \mathrm{Fe}_{3} \mathrm{O}_{4}$ binary nanofluid were used. It was confirmed that the efficiency of the solar collector was noticeably improved when the MWCNT/ $\mathrm{Fe}_{3} \mathrm{O}_{4}$ binary nanofluid was used, compared to that when water was used. When water was applied to the flat plate solar collector, the maximum efficiency was $62.7 \%$. In the case of $\mathrm{MWCNT} / \mathrm{Fe}_{3} \mathrm{O}_{4}$ binary nanofluid, when Case 3 was used as a working fluid in the flat plate solar collector, the efficiency was the highest, and it was $80.3 \%$, which was $28.1 \%$ higher than that when water was used. The maximum efficiencies of the flat plate solar collector for using Case1, Case2, and Case4 were 76.9\%, 73.5\%, and 75.9\%, respectively. These were $22.6 \%, 17.2 \%$, and $21.1 \%$ enhanced efficiency, respectively, compared to that using water. In the previous study [31], when MWCNT and $\mathrm{Fe}_{3} \mathrm{O}_{4}$ nanofluid were individually applied to the flat plate solar collector, the optimum concentrations of MWCNT and $\mathrm{Fe}_{3} \mathrm{O}_{4}$ nanofluid were 0.005 vol. $\%$ and 0.015 vol. $\%$, respectively. In this study, the mixture of optimal concentration for individual MWCNT and $\mathrm{Fe}_{3} \mathrm{O}_{4}$ nanofluid was Case4. Thus, it was confirmed that the efficiency of Case3 was higher than that of Case4, even though Case 3 had lower total concentration than Case4. This is because the dispersion stability of the MWCNT/ $/ \mathrm{Fe}_{3} \mathrm{O}_{4}$ binary nanofluid decreases while the binding of two nanofluids increases as the concentration of the $\mathrm{MWCNT} / \mathrm{Fe}_{3} \mathrm{O}_{4}$ binary nanofluid increases, thereby increasing the aggregation phenomenon in the nanofluid. That means the size increase of nanoparticles 
per unit volume and a decrease in the number of single particles in the nanofluid. Therefore, the efficiency of the solar collector decreases due to the decrease in heat transfer and heat absorption capacity of the nanofluid.

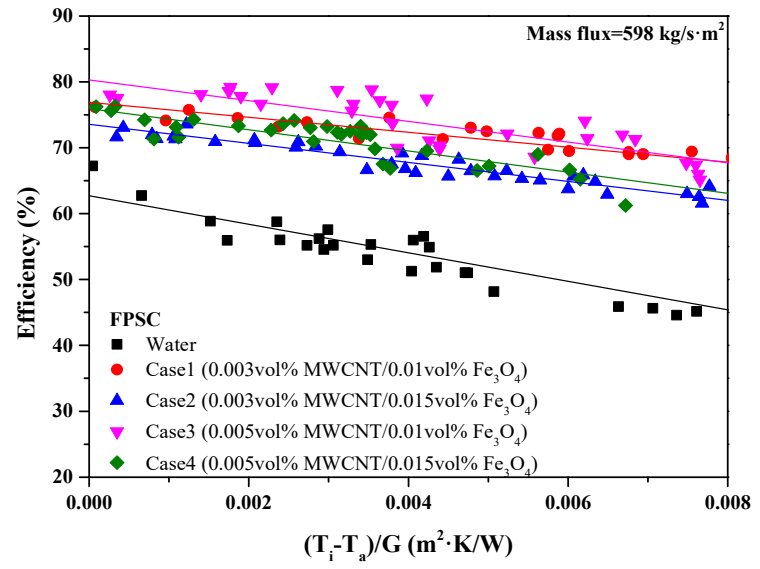

(a) Flat plate solar collector

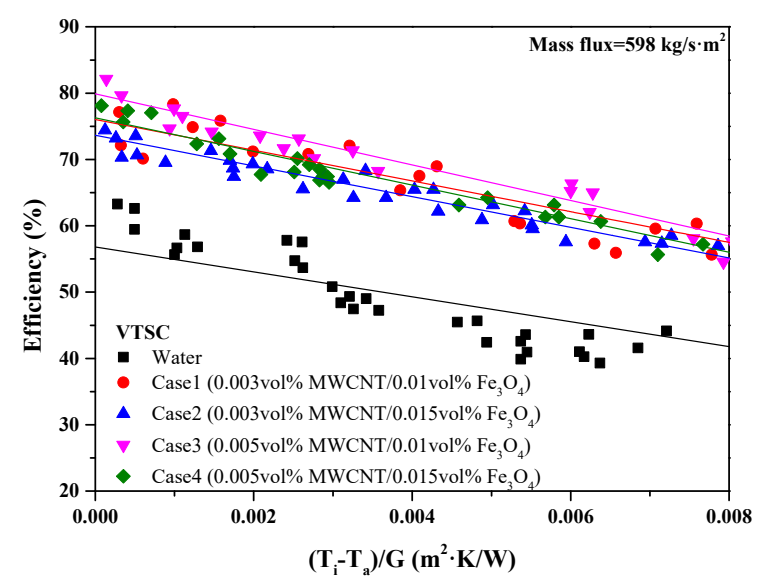

(b) Vacuum tube solar collector

Figure 5. The efficiency of the flat plate and vacuum tube solar collector using water and MWCNT/ $/ \mathrm{Fe}_{3} \mathrm{O}_{4}$ binary nanofluid (Mass flux $=598 \mathrm{~kg} / \mathrm{s} \cdot \mathrm{m}^{2}$ ).

Figure $5 \mathrm{~b}$ shows the efficiency of the vacuum tube solar collector at various concentration conditions when water and $\mathrm{MWCNT} / \mathrm{Fe}_{3} \mathrm{O}_{4}$ binary nanofluid were used. The performance of the vacuum tube solar collector showed a similar trend to that of the flat plate solar collector. The maximum efficiency was $54.9 \%$ when water was used for the vacuum tube solar collector. When Case3 was applied to the vacuum tube solar collector, the maximum efficiency was $79.3 \%$, which was $45.4 \%$ higher than that when water was used. The maximum capabilities were $76.1 \%, 73.6 \%$, and $76.2 \%$, respectively, for Case1, Case2, and Case4 as the working fluid in the vacuum tube solar collector. These showed $38.6 \%, 34.1 \%$, and $38.7 \%$ enhanced efficiency over the efficiency using water. In addition, it was also found that when Case 3 was used, the maximum efficiency of the vacuum tube solar collector was improved by $4.7 \%$, compared with that when Case 4 was used. The maximum capabilities of the flat plate and the vacuum tube solar collector when water was used were $62.7 \%$ and $54.9 \%$, respectively. The maximum efficiency of a flat plate solar collector was about $12.4 \%$ higher than that of the vacuum tube solar collector. Moreover, the maximum capabilities of each solar collector using MWCNT/ $\mathrm{Fe}_{3} \mathrm{O}_{4}$ binary nanofluid (Case3) were $80.3 \%$ and $79.8 \%$, respectively. The flat plate solar collector showed $0.62 \%$ higher efficiency than the vacuum tube solar collector. It was confirmed that when the MWCNT/ $/ \mathrm{Fe}_{3} \mathrm{O}_{4}$ binary nanofluid was used, the efficiency difference between the flat plate and vacuum tube solar collector was significantly decreased. When MWCNT/ $/ \mathrm{Fe}_{3} \mathrm{O}_{4}$ nanofluid was applied to the flat plate solar collector, the performance decreased rapidly with the increase of the temperature parameter, which is the low outdoor temperature condition. Meanwhile, the application of $\mathrm{MWCNT} / \mathrm{Fe}_{3} \mathrm{O}_{4}$ binary nanofluid to the vacuum tube solar collector could maintain high performance not only in high temperatures but also in low temperatures. Therefore, when the MWCNT/ $\mathrm{Fe}_{3} \mathrm{O}_{4}$ binary nanofluid was applied to the vacuum tube solar collector, the efficiency improvement was much higher compared with the flat plate solar collector.

Figure $6 \mathrm{a}, \mathrm{b}$ shows the increase in the heat gain and heat loss parameters, which are directly associated with efficiency, when applying $\mathrm{MWCNT} / \mathrm{Fe}_{3} \mathrm{O}_{4}$ binary nanofluid to the flat plate and the vacuum tube solar collectors, compared with the efficiency when water was used in the flat plate solar collector. Generally, the flat plate solar collector is the most widely used solar collector in the world, and water is a primary working fluid. Thus, in this study, the base condition is defined as the efficiency of the flat plate solar collector when water with a mass flux of $420 \mathrm{~kg} / \mathrm{s} \cdot \mathrm{m}^{2}$ was used. In the effectiveness of the solar collector, the $F_{R}(\tau \alpha)$ is the heat gain parameter, and represents the intersection of the y-axis 
with the heat gain parameter, and is determined by the thermal absorption rate of the solar collector. The $F_{R} U_{L}$ is the heat loss parameter, which indicates the slope of the curve inefficiency. Therefore, the solar collector with the larger $F_{R}(\tau \alpha)$ and the smaller $F_{R} U_{L}$ is, the better one. Figure 6a shows the increase of $F_{R}(\tau \alpha)$ of the flat plate and vacuum tube solar collector when water and $\mathrm{MWCNT} / \mathrm{Fe}_{3} \mathrm{O}_{4}$ binary nanofluid were used, compared to the base condition. The application of water to the vacuum tube solar collector reduced the $F_{R}(\tau \alpha)$ of the solar collector by $12.4 \%$, compared to the flat plate solar collector. When Case3 (0.005 vol.\% MWCNT/0.01 vol. $\% \mathrm{Fe}_{3} \mathrm{O}_{4}$ binary nanofluid) was applied to the solar collector, $F_{R}(\tau \alpha)$ was improved by $28.1 \%$ and $27.3 \%$, respectively, in the flat plate and vacuum tube solar collector, compared to the base condition. In addition, the application of Case1 improved the efficiency by about $22.6 \%$ and $21.4 \%$, respectively, for the flat plate and vacuum tube solar collector, compared with that when water was used. Case1 and Case 3 achieved a 5.97\% and 2.92\% improvement, respectively, in the flat plate solar collector efficiency over the use of the vacuum tube solar collector. However, for Case 2 and Case4, the effectiveness of the flat plate solar collector showed a $0.93 \%$ and $2.22 \%$ decrease, respectively, compared to that of the vacuum tube solar collector. Both Case 3 and Case 1 have $\mathrm{Fe}_{3} \mathrm{O}_{4}$ concentration of $0.01 \mathrm{vol} . \%$ and have relatively more stable dispersion stability than Case 2 and Case 4 with $0.015 \% \mathrm{Fe}_{3} \mathrm{O}_{4}$ concentration. Therefore, it was confirmed that the performance of the solar collector could be further improved at the optimum concentration with stable dispersion stability compared with the application of the high-concentration nanofluid with improved properties and low dispersion stability in the solar collector. In this study, high-concentration binary nanofluid with low dispersion stability decreased heat energy transfer and absorption capacity. Thus, the $F_{R}(\tau \alpha)$ of the vacuum tube solar collector for Case 2 and Case4 increased, compared to that of the flat plate solar collector. Accordingly, the use of high-concentration binary nanofluid with stable dispersion stability can significantly improve the performance of the vacuum tube solar collector. Generally, it is essential to use the solar collector for a long time more than ten years after installation. The decrease in the thermal properties of the working fluid leads to a reduction in the efficiency of the solar collector, which can drastically reduce the economic efficiency of solar collector system. Therefore, when the nanofluid is used commercially as the working fluid in the solar collector, the dispersion stability of the nanofluid can be an important influence on economic efficiency.

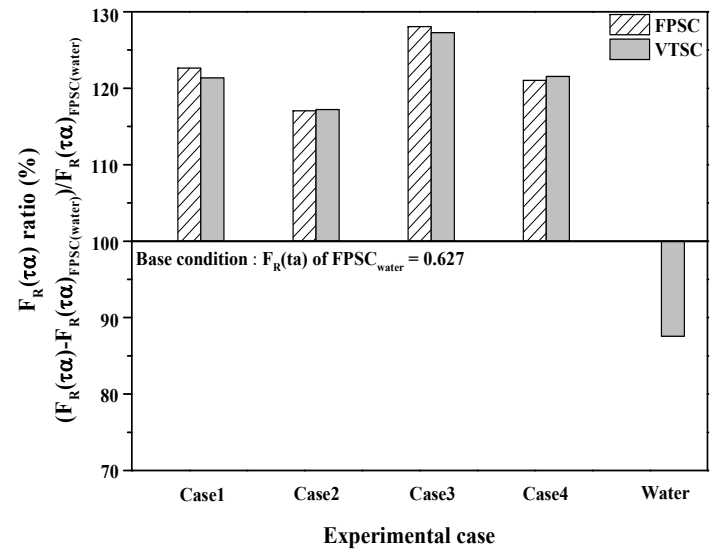

(a) Heat gain parameter $\left(F_{R}(\tau \alpha)\right)$

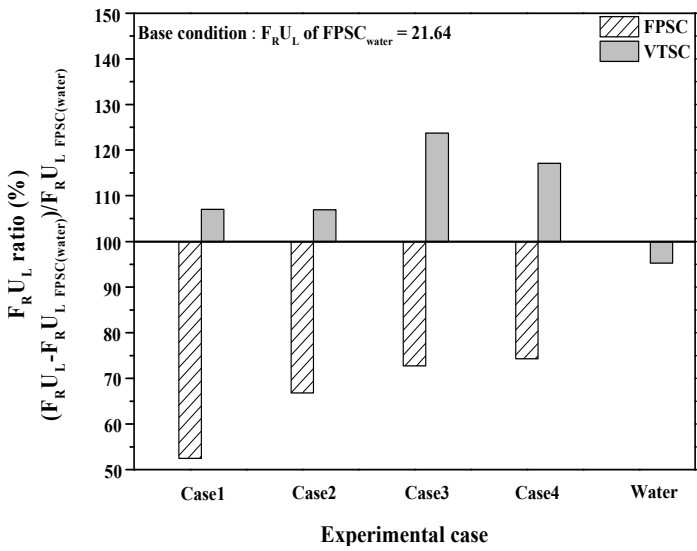

(b) Heat loss parameter $\left(F_{R} U_{L}\right)$

Figure 6. $F_{R}(\tau \alpha)$ and $F_{R} U_{L}$ ratio of a solar collector using water and $\mathrm{MWCNT} / \mathrm{Fe}_{3} \mathrm{O}_{4}$ nanofluid.

Figure $6 \mathrm{~b}$ shows the increase of $F_{R} U_{L}$ of the solar collector when $\mathrm{MWCNT} / \mathrm{Fe}_{3} \mathrm{O}_{4}$ binary nanofluid was used, compared to that when water was used for the flat plate solar collector (base condition). The application of water to the vacuum tube solar collector brought a $4.76 \%$ reduction in $F_{R} U_{L}$ of solar collector, compared to the base condition. In the case of using MWCNT/ $/ \mathrm{Fe}_{3} \mathrm{O}_{4}$ binary nanofluid, the $F_{R} U_{L}$ of the flat plate solar collector decreased, compared to the application of water. Still, the $F_{R} U_{L}$ increased slightly for the vacuum tube solar collector. When Case3 was used, the $F_{R} U_{L}$ of the flat plate 
and vacuum tube solar collector compared to the base condition showed a $27.3 \%$ reduction and a $23.7 \%$ enhancement, respectively. In the case of Case1, a $47.6 \%$ reduction and $7.02 \%$ enhancement of $F_{R} U_{L}$ in the flat plate and vacuum tube solar collector, respectively, compared to the base condition were found. Applying MWCNT/ $/ \mathrm{Fe}_{3} \mathrm{O}_{4}$ binary nanofluid to the flat plate solar collector would reduce heat losses by up to $47.6 \%$ compared to water. Still, it increased heat losses by $23.7 \%$ in the vacuum tube solar collector, compared to the base condition. Therefore, when the MWCNT/ $/ \mathrm{Fe}_{3} \mathrm{O}_{4}$ binary nanofluid was applied, the heat gain parameter $\left(F_{R}(\tau \alpha)\right)$ was increased by $17.1 \%-28.1 \%$ in the flat plate solar collector, and $17.2-27.3 \%$ in the vacuum tube solar collector, respectively. The heat The loss parameter $\left(F_{R} U_{L}\right)$ was reduced by $25.7 \%-47.6 \%$ in the flat plate solar collector, while it was increased by $6.93-17.1 \%$ in the vacuum tube solar collector. When the MWCNT/ $/ \mathrm{Fe}_{3} \mathrm{O}_{4}$ binary nanofluid was used in the solar collector, the maximum efficiency of the flat plate and vacuum tube solar collector increased simultaneously. In addition, the heat loss parameter was reduced for the flat plate solar collector, while the heat loss parameter was increased for the vacuum tube solar collector. Thus, it can be seen that the application of MWCNT/ $/ \mathrm{Fe}_{3} \mathrm{O}_{4}$ binary nanofluid to the solar collector should consider their characteristics, depending on the operating conditions and type of solar collector.

Figure 7 a shows the temperature increase of working fluid in the flat plate solar collector when $\mathrm{MWCNT} / \mathrm{Fe}_{3} \mathrm{O}_{4}$ binary nanofluid was applied. When $\mathrm{MWCNT} / \mathrm{Fe}_{3} \mathrm{O}_{4}$ binary nanofluid was applied as a working fluid to the flat plate solar collector, Case3 shows the largest temperature increase in the solar collector. The temperature increased in the order Case $3<$ Case $2<$ Case $4<$ Case 1 for relatively low solar radiation, such as $300-500 \mathrm{~W} / \mathrm{m}^{2}$, and then it changed to the order Case $3<$ Case $4<$ Case $2<$ Case 1 for high solar radiation. Figure $7 \mathrm{~b}$ shows the temperature increase of working fluid in the vacuum tube solar collector when MWCNT/ $/ \mathrm{Fe}_{3} \mathrm{O}_{4}$ binary nanofluid was applied. When the $\mathrm{MWCNT} / \mathrm{Fe}_{3} \mathrm{O}_{4}$ binary nanofluid was applied as a working fluid to a vacuum tube solar collector, the temperature of the working fluid increased in the order Case $4<$ Case $2<$ Case $1<$ Case 3 for $300-450 \mathrm{~W} / \mathrm{m}^{2}$. Then it changed to the order Case $3<$ Case $2<$ Case $4<$ Case 1 for high solar radiation. The temperature increase of working fluid in the vacuum tube solar collector varied more than that in the flat plate solar collector for relatively low solar radiation of 300-500 W/ $\mathrm{m}^{2}$. However, since the slope of the temperature change of the flat plate solar collector was steeper, it is confirmed that the A temperature increase of working fluid in the flat plate solar collector varied more significantly for $500-650 \mathrm{~W} / \mathrm{m}^{2}$.

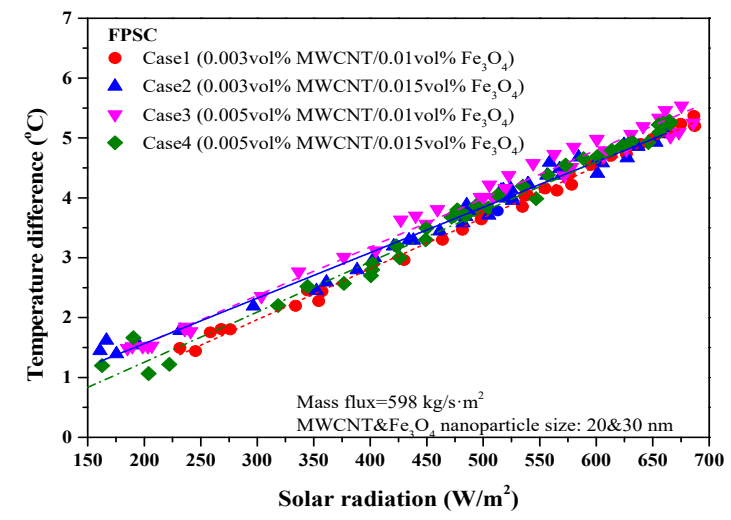

(a) Flat plate solar collector

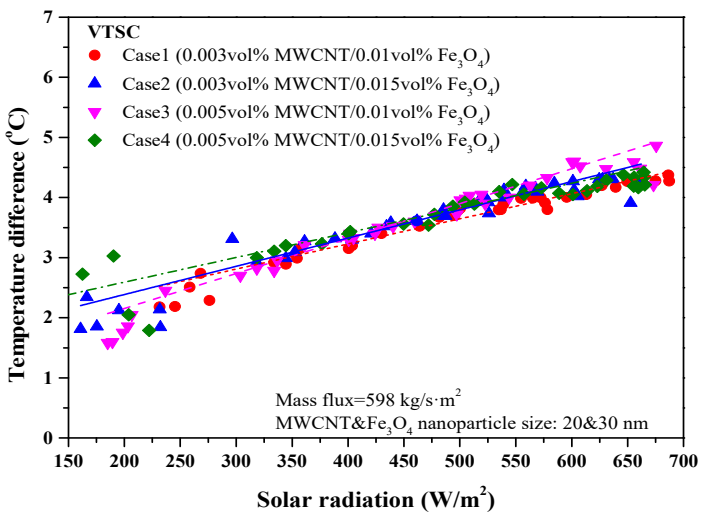

(b) Vacuum tube solar collector

Figure 7. Variation of temperature difference in the flat plate and vacuum tube solar collector depending on solar radiation.

Figure 8 shows the variation of efficiency for two solar collectors according to the mass flux of working fluid. In this study, the water and Case 3 as the working fluid, and 420 and $598 \mathrm{~kg} / \mathrm{s} \cdot \mathrm{m}^{2}$ as mass flux, were used, respectively. Figure 8a shows that when the mass flux of MWCNT/ $/ \mathrm{Fe}_{3} \mathrm{O}_{4}$ binary nanofluid was changed from 420 to $598 \mathrm{~kg} / \mathrm{s} \cdot \mathrm{m}^{2}$, the efficiency of the flat plate solar collector was increased by $7.8 \%$. In the case of water, for the same mass flux change, it was increased by $6.5 \%$. 
The efficiency of the flat plate solar collector was more sensitive to the change of mass flux in the $\mathrm{MWCNT} / \mathrm{Fe}_{3} \mathrm{O}_{4}$ binary nanofluid, than that of water. In this study, the maximum efficiency of the flat plate solar collector using Case 3 was $74.5 \%$ and $80.3 \%$ at the mass fluxes of 420 and $598 \mathrm{~kg} / \mathrm{s} \cdot \mathrm{m}^{2}$, respectively. Figure $8 \mathrm{~b}$ shows the efficiency variation of the vacuum tube solar collector according to mass flux when MWCNT/ $/ \mathrm{Fe}_{3} \mathrm{O}_{4}$ binary nanofluid (Case3) and water were used. When the mass flux of the vacuum tube solar collector was 420 , and $598 \mathrm{~kg} / \mathrm{s} \cdot \mathrm{m}^{2}$, the maximum efficiency of the vacuum tube solar collector using Case 3 was $73.7 \%$ and $79.8 \%$, respectively. The effectiveness of the vacuum tube solar collector using Case 3 was increased by $8.3 \%$ for the change of mass flux, and in the case of water, it was $7.4 \%$. It was confirmed that by increasing the mass flux of the working fluid in the flat plate and the vacuum tube solar collector, simultaneously, the efficiency of the solar collector was increased. At the mass flux of $420 \mathrm{~kg} / \mathrm{s} \cdot \mathrm{m}^{2}$, the maximum efficiency of the flat plate and the vacuum tube solar collector was $74.5 \%$ and $73.7 \%$, respectively, and the effectiveness of the flat plate solar collector was $1.0 \%$ higher than that of the vacuum tube solar collector. At the mass flux of $598 \mathrm{~kg} / \mathrm{s} \cdot \mathrm{m}^{2}$, the maximum efficiency was $80.3 \%$ and $79.8 \%$ for the flat plate and the vacuum tube solar collector, respectively. The effectiveness of the flat plate solar collector showed $0.62 \%$ higher efficiency than that of the vacuum tube solar collector. In the case of water, the maximum efficiency of the flat plate and vacuum tube solar collector was $58.9 \%$ and $51.1 \%$ for the mass flux of $420 \mathrm{~kg} / \mathrm{s} \cdot \mathrm{m}^{2}$, and $62.7 \%$ and $54.9 \%$ for the mass flux of $598 \mathrm{~kg} / \mathrm{s} \cdot \mathrm{m}^{2}$, respectively. In addition, when the mass flux was varied from 420 to 598 $\mathrm{kg} / \mathrm{s} \cdot \mathrm{m}^{2}$, the maximum efficiencies of the flat plate solar collector and vacuum tube solar collector were increased by $6.4 \%$ and $7.4 \%$, respectively. As the mass flux of the working fluid increases, the strength of mixing and the turbulence between nanoparticles are increased, and these increases, in turn, increase the heat transfer coefficient and the Nu number. Therefore, more active heat transfer phenomenon occurs, and this noticeably increases the efficiency of the solar collector.

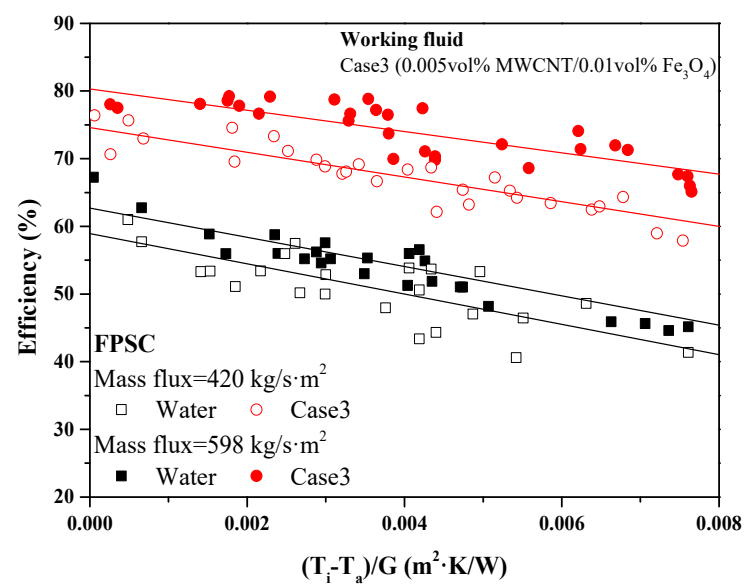

(a) Flat plate solar collector

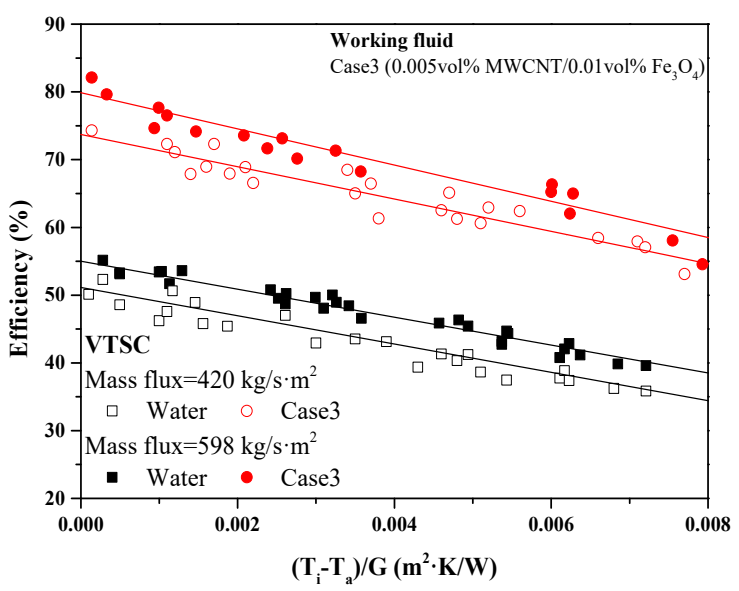

(b) Vacuum tube solar collector

Figure 8. Variation of efficiency in the flat plate and vacuum tube solar collector depending on the mass flux of working fluid.

Figure $9 \mathrm{a}$,b shows the increase of $F_{R}(\tau \alpha)$ and $F_{R} U_{L}$ when the MWCNT/ $/ \mathrm{Fe}_{3} \mathrm{O}_{4}$ binary nanofluid (Case3) was applied to the flat plate and vacuum tube solar collector, compared with those in the base condition. To compare $F_{R}(\tau \alpha)$ and $F_{R} U_{L}$ according to the change of the mass flux of the working fluid between nanofluid and water, Case $3 \mathrm{MWCNT} / \mathrm{Fe}_{3} \mathrm{O}_{4}$ binary nanofluid was used, which showed the maximum efficiency among the $\mathrm{MWCNT} / \mathrm{Fe}_{3} \mathrm{O}_{4}$ binary nanofluids. In the base condition, $F_{R}(\tau \alpha)$ and $F_{R} U_{L}$ in the flat plate solar collector using water at a mass flux of $420 \mathrm{~kg} / \mathrm{s} \cdot \mathrm{m}^{2}$ were 0.589 and 22.36, respectively. Figure 9 a shows the increase of $F_{R}(\tau \alpha)$ when water and Case3 are applied to the flat plate and vacuum tube solar collector with a mass flux of 420 and $598 \mathrm{~kg} / \mathrm{s} \cdot \mathrm{m}^{2}$, compared to the base condition. $F_{R}(\tau \alpha)$ was reduced by $13.3 \%$ when water with a mass flux of $420 \mathrm{~kg} / \mathrm{s} \cdot \mathrm{m}^{2}$ was applied to the vacuum tube solar collector. On the other hand, when Case 3 with a mass flux of $420 \mathrm{~kg} / \mathrm{s} \cdot \mathrm{m}^{2}$ 
was used, $F_{R}(\tau \alpha)$ improved by $26.5 \%$ and $25.1 \%$, respectively, for the flat plate and vacuum tube solar collector. The $F_{R}(\tau \alpha)$ showed a tendency to increase with increasing mass flux of the working fluid. When water with a mass flux of $598 \mathrm{~kg} / \mathrm{s} \cdot \mathrm{m}^{2}$ was used, $F_{R}(\tau \alpha)$ of the flat plate solar collector increased by $6.45 \%$, while that of the vacuum tube solar collector decreased by $6.79 \%$, compared to the base condition. The application of water as a working fluid to the vacuum tube solar collector improved $F_{R}(\tau \alpha)$ by $7.43 \%$ when the mass flux increased from 420 to $598 \mathrm{~kg} / \mathrm{s} \cdot \mathrm{m}^{2}$. For the same change of mass flux in the working fluid, when Case 3 was applied, $F_{R}(\tau \alpha)$ of the flat plate and vacuum tube solar collector increased by $36.3 \%$ and $35.5 \%$, respectively.

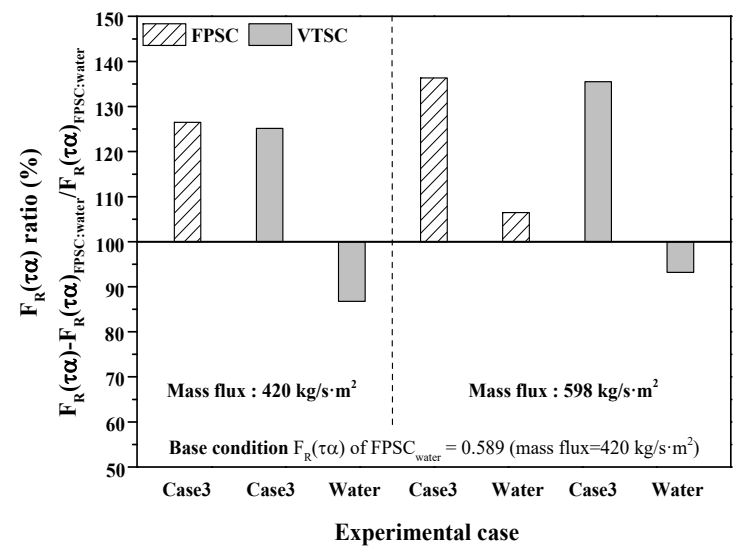

(a) Heat gain parameter $\left(F_{R}(\tau \alpha)\right)$

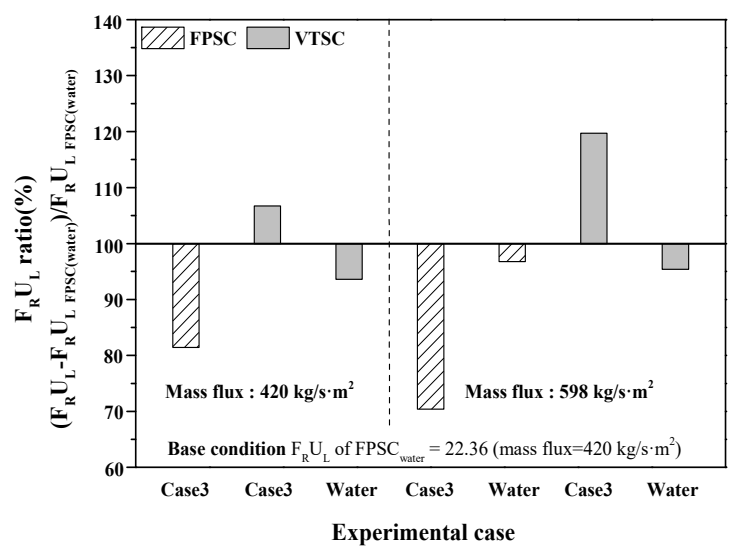

(b) Heat loss parameter $\left(F_{R} U_{L}\right)$

Figure 9. $F_{R}(\tau \alpha)$ and $F_{R} U_{L}$ ratio at different mass fluxes of water and $\mathrm{MWCNT} / \mathrm{Fe}_{3} \mathrm{O}_{4}$ nanofluid.

Figure $9 \mathrm{~b}$ shows the increase of $F_{R} U_{L}$ when water and Case3 were applied to the flat plate and vacuum tube solar collector at a mass flux of 420 and $598 \mathrm{~kg} / \mathrm{s} \cdot \mathrm{m}^{2}$, compared to the base condition. In the vacuum tube solar collector, $F_{R} U_{L}$ was reduced by $6.39 \%$ by applying water at a mass flux of 420 $\mathrm{kg} / \mathrm{s} \cdot \mathrm{m}^{2}$, compared to the base condition. In Case3, MWCNT/ $/ \mathrm{Fe}_{3} \mathrm{O}_{4}$ binary nanofluid with a mass flux of $420 \mathrm{~kg} / \mathrm{s} \cdot \mathrm{m}^{2}, F_{R} U_{L}$ showed $18.6 \%$ reduction for the flat plate solar collector and $6.71 \%$ enhancement for the vacuum tube solar collector. As the mass flux increased, $F_{R} U_{L}$ decreased by $3.22 \%$ and $4.61 \%$ for the flat plate and vacuum tube solar collector, compared to the base condition. In the case that water was used in the vacuum tube solar collector when the mass flux was increased from 420 to 598 $\mathrm{kg} / \mathrm{s} \cdot \mathrm{m}^{2}, F_{R} U_{L}$ was reduced by $1.53 \%$.

\section{Conclusions}

In this study, the efficiency of a solar collector was experimentally analyzed by applying water and MWCNT/ $/ \mathrm{Fe}_{3} \mathrm{O}_{4}$ binary nanofluid to the flat plate and vacuum tube solar collector. MWCNT/ $/ \mathrm{Fe}_{3} \mathrm{O}_{4}$ binary nanofluids with four mixing ratios between MWCNT and $\mathrm{Fe}_{3} \mathrm{O}_{4}$ were manufactured and used as the working fluid of the two kinds of solar collectors. As a result, it was found that applying Case 3 (0.005 vol.\% MWCNT/0.01 vol. $\% \mathrm{Fe}_{3} \mathrm{O}_{4}$ binary nanofluid) to the flat plate solar collector showed the highest efficiency, which was $80.3 \%$ and $28.1 \%$ enhancement over the application of water. In the case of the vacuum tube solar collector, the use of Case3 binary nanofluid showed the highest efficiency (79.8\%), which is $45.4 \%$ improvement over the application of water. When the MWCNT/ $\mathrm{Fe}_{3} \mathrm{O}_{4}$ binary nanofluid was used as the working fluid in the flat plate and vacuum tube solar collector, it was confirmed that the efficiency was significantly improved, compared to the water. When water was used, the maximum efficiency of flat plate solar collector was about $12.4 \%$ higher than that of the vacuum tube solar collector; while when $\mathrm{MWCNT} / \mathrm{Fe}_{3} \mathrm{O}_{4}$ binary nanofluid (Case3) was used, it was $0.5 \%$. Therefore, when the MWCNT/ $\mathrm{Fe}_{3} \mathrm{O}_{4}$ binary nanofluid was applied to the vacuum tube solar collector, the efficiency improvement was much higher compared with the flat plate solar collector. In 
addition, the MWCNT/ $\mathrm{Fe}_{3} \mathrm{O}_{4}$ binary nanofluid was applied to two solar collectors, the efficiency was improved more than $25 \%$, which can have significant economically benefits compared to the water.

Author Contributions: Conceptualization, H.C. and M.L.; methodology Y.S.; validation, H.C., M.L. and Y.S.; formal analysis, Y.S.; investigation, M.L.; resources, H.C.; writing-original draft preparation, M.L.; writing-review and editing, H.C. and Y.S.; supervision, H.C. All authors have read and agreed to the published version of the manuscript.

Funding: This research was supported by the Basic Science Research Program through the National Research Foundation of Korea (NRF) funded by the Ministry of Science, ICT \& Future Planning (NRF-2020R1A2C2008248) and Human Resources Program in Energy Technology of the Korea Institute of Energy Technology Evaluation and Planning (KETEP), granted financial resources from the Ministry of Trade, Industry \& Energy, Republic of Korea (No. 20194030202410).

Conflicts of Interest: The authors declare no conflict of interest. The funders had no role in the design of the study; in the collection, analyses, or interpretation of data; in the writing of the manuscript, or in the decision to publish the results.

\section{References}

1. Bórawski, P.; Bełdycka-Bórawska, A.; Szymańska, E.J.; Jankowski, K.J.; Dubis, B.; Dunn, J.W. Development of renewable energy sources market and biofuels in The European Union. J. Clean. Prod. 2019, 228, 467-484. [CrossRef]

2. Jouybari, H.J.; Saedodin, S.; Zamzamian, A.; Nimvari, M.E.; Wongwises, S. Effects of porous material and nanoparticles on the thermal performance of a flat plate solar collector: An experimental study. Renew. Energy 2017, 114, 1407-1418. [CrossRef]

3. Azad, E. Experimental analysis of thermal performance of solar collectors with different numbers of heat pipes versus a flow-through solar collector. Renew. Sustain. Energy Rev. 2018, 82, 4320-4325. [CrossRef]

4. Gunjo, D.G.; Mahanta, P.; Robi, P.S. Exergy and energy analysis of a novel type solar collector under steady state condition: Experimental and CFD analysis. Renew. Energy 2017, 114, 655-669. [CrossRef]

5. Gao, Y.; Gao, C.; Xian, H.; Du, X. Thermal Properties of Solar Collector Comprising Oscillating Heat Pipe in a Flat-Plate Structure and Water Heating System in Low-Temperature Conditions. Energies 2018, 11, 2553. [CrossRef]

6. Montoya-Márquez, O.; Flores-Prieto, J. Heat Removal Factor in Flat Plate Solar Collectors: Indoor Test Method. Energies 2018, 11, 2783. [CrossRef]

7. Karvounis, P.; Koubogiannis, D.; Hontzopoulos, E.; Hatziapostolou, A. Numerical and Experimental Study of Flow Characteristics in Solar Collector Manifolds. Energies 2019, 12, 1431. [CrossRef]

8. Yousefi, T.; Veysi, F.; Shojaeizadeh, E.; Zinadini, S. An experimental investigation on the effect of $\mathrm{Al}_{2} \mathrm{O}_{3}-\mathrm{H}_{2} \mathrm{O}$ nanofluid on the efficiency of flat-plate solar collectors. Renew. Energy 2012, 39, 293-298. [CrossRef]

9. Said, Z.; Saidur, R.; Rahim, N.A. Energy and exergy analysis of a flat plate solar collector using different sizes of aluminium oxide based nanofluid. J. Clean. Prod. 2016, 133, 518-530. [CrossRef]

10. Yousefi, T.; Veisy, F.; Shojaeizadeh, E.; Zinadini, S. An experimental investigation on the effect of MWCNT- $\mathrm{H}_{2} \mathrm{O}$ nanofluid on the efficiency of flat-plate solar collectors. Exp. Therm. Fluid Sci. 2012, 39, 207-212. [CrossRef]

11. Sharafeldin, M.A.; Gróf, G. Experimental investigation of flat plate solar collector using $\mathrm{CeO}_{2}$-water nanofluid. Energy Convers. Manag. 2018, 155, 32-41. [CrossRef]

12. Sharafeldin, M.A.; Gróf, G. Efficiency of evacuated tube solar collector using $\mathrm{WO}_{3} /$ Water nanofluid. Renew. Energy 2019, 134, 453-460. [CrossRef]

13. Sharafeldin, M.A.; Gróf, G. Evacuated tube solar collector performance using $\mathrm{CeO}_{2} /$ water nanofluid. J. Clean. Prod. 2018, 185, 347-356. [CrossRef]

14. Li, Y.; Xie, H.Q.; Yu, W.; Li, J. Investigation on Heat Transfer Performances of Nanofluids in Solar Collector. Mater. Sci. Forum 2011, 694, 33-36. [CrossRef]

15. Tong, Y.; Kim, J.; Cho, H. Effects of thermal performance of enclosed-type evacuated U-tube solar collector with multi-walled carbon nanotube/water nanofluid. Renew. Energy 2015, 83, 463-473. [CrossRef]

16. Tong, Y.; Cho, H. Comparative Study on the Thermal Performance of Evacuated Solar Collectors with U-Tubes and Heat Pipes. Int. J. Air Cond. Refrig. 2015, 23, 1550019. [CrossRef]

17. Tyagi, H.; Phelan, P.; Prasher, R. Predicted efficiency of a low-temperature nanofluid-based direct absorption solar collector. J. Sol. Energy Eng. 2009, 131, 041004. [CrossRef] 
18. Khullar, V.; Tyagi, H.; Phelan, P.E.; Otanicar, T.P.; Singh, H.; Taylor, R.A. Solar Energy Harvesting Using Nanofluids-Based Concentrating Solar Collector. J. Nanotechnol. Eng. Med. 2013, 3. [CrossRef]

19. Otanicar, T.P.; Phelan, P.E.; Prasher, R.S.; Rosengarten, G.; Taylor, R.A. Nanofluid based direct absorption solar collector. J. Renew. Sustain. Energy 2010, 2, 033102. [CrossRef]

20. Kang, W.; Shin, Y.; Cho, H. Economic Analysis of Flat-Plate and U-Tube Solar Collectors Using an $\mathrm{Al}_{2} \mathrm{O}_{3}$ Nanofluid. Energies 2017, 10, 1911. [CrossRef]

21. Otanicar, T.; Golden, J. Comparative Environmental and Economic Analysis of Conventional and Nanofluid Solar Hot Water Technologies. Environ. Sci. Technol. 2019, 43, 6082-6087. [CrossRef] [PubMed]

22. Menbari, A.; Alemrajabi, A.A.; Ghayeb, Y. Investigation on the stability, viscosity and extinction coefficient of $\mathrm{CuO}-\mathrm{Al}_{2} \mathrm{O}_{3} /$ Water binary mixture nanofluid. Exp. Therm. Fluid Sci. 2016, 74, 122-129. [CrossRef]

23. Zeng, J.; Xuan, Y. Enhanced solar thermal conversion and thermal conduction of $\mathrm{MWCNT}_{-} \mathrm{SiO}_{2} / \mathrm{Ag}$ binary nanofluids. Appl. Energy 2018, 212, 809-819. [CrossRef]

24. Menbari, A.; Alemrajabi, A.A.; Rezaei, A. Experimental investigation of thermal performance for direct absorption solar parabolic trough collector (DASPTC) based on binary nanofluids. Exp. Therm. Fluid Sci. 2017, 80, 218-227. [CrossRef]

25. Dalkılıç, A.S.; Yalçın, G.; Küçükyıldırım, B.O.; Öztuna, S.; Akdoğan Eker, A.; Jumpholkul, C.; Nakkaew, S.; Wongwises, S. Experimental study on the thermal conductivity of water-based $\mathrm{CNT}^{-\mathrm{SiO}_{2}}$ hybrid nanofluids. Int. Commun. Heat Mass Transf. 2018, 99, 18-25. [CrossRef]

26. Fu, R.; Liu, Z.; Chen, Y.; Yan, Y. Experimental investigation of turbulent forced heat transfer of $\mathrm{Fe}_{3} \mathrm{O}_{4}$ ethylene glycol-Water nanofluid with highly disaggregated particles. Therm. Sci. Eng. Prog. 2019, 10, 1-9. [CrossRef]

27. Qu, J.; Zhang, R.; Wang, Z.; Wang, Q. Photo-thermal conversion properties of hybrid CuO-MWCNT/ $\mathrm{H}_{2} \mathrm{O}$ nanofluids for direct solar thermal energy harvest. Appl. Therm. Eng. 2019, 147, 390-398. [CrossRef]

28. Shi, L.; He, Y.; Hu, Y.; Wang, X. Thermophysical properties of $\mathrm{Fe}_{3} \mathrm{O}_{4} @ \mathrm{CNT}$ nanofluid and controllable heat transfer performance under magnetic field. Energy Convers. Manag. 2018, 177, 249-257. [CrossRef]

29. Sarbolookzadeh Harandi, S.; Karimipour, A.; Afrand, M.; Akbari, M.; D'Orazio, A. An experimental study on thermal conductivity of F-MWCNTs- $\mathrm{Fe}_{3} \mathrm{O}_{4} / \mathrm{EG}$ hybrid nanofluid: Effects of temperature and concentration. Int. Commun. Heat Mass Transf. 2016, 76, 171-177. [CrossRef]

30. Jung, J.-Y.; Cho, C.; Lee, W.H.; Kang, Y.T. Thermal conductivity measurement and characterization of binary nanofluids. Int. J. Heat Mass Transf. 2011, 54, 1728-1733. [CrossRef]

31. Kang, W.; Cho, H. Performance analysis of U-tube solar collector according to the concentration of MWCNT nanofluid. In Proceedings of the Society of Air-Conditioning and Refrigerating Engineers of Korea Conference, Seoul, Korea, 23 November 2018.

32. Sundar, L.S.; Sharma, K.V. Thermal conductivity enhancement of nanofluid in distilled water. Int. J. Nanopart. 2008, 1, 66-77. [CrossRef]

33. Pak, B.C.; Cho, Y.I. Hydrodynamic and Heat Transfer Study of Dispersed Fluids with Submicron Metallic Oxide Particles. Exp. Heat Transf. 1998, 11, 151-170. [CrossRef]

34. Hemmat Esfe, M.; Alirezaie, A.; Rejvani, M. An applicable study on the thermal conductivity of SWCNT-MgO hybrid nanofluid and price-performance analysis for energy management. Appl. Therm. Eng. 2017, 111, 1202-1210. [CrossRef]

35. Moffat, R.J. Using Uncertainty Analysis in the Planning of an Experiment. J. Fluids Eng. 1985, 107, 173. [CrossRef]

(C) 2020 by the authors. Licensee MDPI, Basel, Switzerland. This article is an open access article distributed under the terms and conditions of the Creative Commons Attribution (CC BY) license (http://creativecommons.org/licenses/by/4.0/). 